$1-1954$

\title{
Marine Fishes in Fresh and Brackish Waters of Virginia Rivers
}

William H. Massman

Virginia Fisheries Laboratory

Follow this and additional works at: https://scholarworks.wm.edu/vimsarticles

Part of the Aquaculture and Fisheries Commons

\section{Recommended Citation}

Massman, William H., "Marine Fishes in Fresh and Brackish Waters of Virginia Rivers" (1954). VIMS Articles. 1765.

https://scholarworks.wm.edu/vimsarticles/1765

This Article is brought to you for free and open access by W\&M ScholarWorks. It has been accepted for inclusion in VIMS Articles by an authorized administrator of W\&M ScholarWorks. For more information, please contact scholarworks@wm.edu. 


\section{MARINE IISHES IN IRRESH AND BRACKISH WATERS OF VIRGINIA RIVERS ${ }^{1}$}

WILLIAM H. MASSMAN

Virginia Fisheries Laboratory, Gloncester Point, Virginia

In the fresh and brackish waters of the James, Chickahominy, Pamunkey, Mattaponi and Rappahannock rivers in Virginia, 18 species of marine fishes (exclusive of anadromous and catadromous forms) have been collected. Gunter's (1942) exhaustive survey of the occurrence of Atlantic coast marine fishes in fresh water is here amplified for the most important tidal rivers of Virginia.

\footnotetext{
${ }^{1}$ Contributions from the Virginia Fisheries Laboratory,
}

Since 1949 intensive collecting las been clone in brackish and ticlal fresh waters of the Pamunkey and Rappahannock rivers, and numerous collections have been made in the James, Chickahominy, and Mattaponi. The samples include 261 collected by minnow seine, 39 by gill net, 12 by rotenone and 81 by surface trawl (Massmann. Ladd, and $\mathrm{McC}$ utcheon 1952). In addition more than 845 plankton net samples, using nets one meter in cliameter at the mouth, were made both No. 47. 
at the surface and near the bottom. Collections were made from February to October inclusive, but summer collecting was most intensive. For convenience in summarizing the data, the rivers were divided into five-mile intervals, and all collections in each interval were lumped. No marine fishes have been taken in these rivers and their tributary creeks beyond the limits of tidal excursion.

Since the boundary of brackish and fresh waters oscillates with the tide, moving one or two miles upstream with the flood and one or two miles clownstream with the ebb, the average location of this boundary has been used. Extremes in rainfall, drought, and wind may displace this boundary by considerable distances. Collections were not made under these extreme conditions.

The marine species taken in brackish (salinity of five parts per thousand or less) and fresh water are listed in Figure 1 . The greatest clistance in nattical miles upriver at which marine fishes were captured, the number of rivers in which they have been collected, and the number of species taken at varying distances upriver from brackish water are indicated. The distances upriver from Chesapeake Bay to the average location of the boundary of brackish and fresh water and the river length from this boundary to the head of the ticle are listed in Table I.

TAILE I. The distance upriver from Chesapeake Bay to the location of the averagc boundary between brackish and fresh water, and the length of the tidal freshwater section for the five major tidal rivers in Virginia.

\begin{tabular}{|c|c|c|}
\hline River & $\begin{array}{l}\text { Distance upriver } \\
\text { from Chesapeake } \\
\text { Bay to location of } \\
\text { average boundary } \\
\text { between brackish } \\
\text { and fresh water } \\
\text { (Nautical miles) }\end{array}$ & $\begin{array}{l}\text { Distance from the } \\
\text { average boundary } \\
\text { between fresh and } \\
\text { brackish water to } \\
\text { the head of tidal } \\
\text { water } \\
\text { (Nautical miles) }\end{array}$ \\
\hline $\begin{array}{l}\text { Inmes........ } \\
\text { Chickahominy } \\
\text { Pamunkey .... } \\
\text { Mattaponi.... } \\
\text { Rappahannock }\end{array}$ & $\begin{array}{l}30 \\
30^{*} \\
30 \\
45\end{array}$ & $\begin{array}{l}55 \\
250 \\
20 \\
30 \\
35 \\
50\end{array}$ \\
\hline
\end{tabular}

:A tributary of thr James River,

Annotated List of Marine Fismis

Brezoortia tyrannus (Latrobe), Menladen.Found in all five rivers, young menhaden were abundant in fresh waters of the Rappahannock River, where they were captured 35 miles upriver from brackish water. Adults have not been collected in fresh waters.

Anchoa mitchilli mitchilli (Valenciennes), Mitchill's anchovy.-Numerous in all rivers, some anchovies were captured 40 miles upstream from brackish water. Adults, young, and postlarvae were abundant in surface trawl collections and some were taken by seine.

Anchoa hepsetus hepsetus (Bonaterre), Anchovy.-A single specimen was obtained from braclish waters in the Mattaponi River.

Strongylura marina (Walbaum), Atlantic needlefish.-Commonly found in fresh waters, several needlefish were collected 40 miles upstream from brackish water. Two were taken at the head of the tide in the Pamunkey River. Most of the specimens were adults. It is possible that the species sometimes spawns in fresh water, for eggs were running freely from a female taken in the Chickahominy River 10 miles above brackisl water on May 9, 1952. A specimen $23 \mathrm{~mm}$. in length was caught in the Pamunkey.

Fundulus majalis (Walbaum), Striped killifish. -A few striped killifish were found in brackish waters of the Pamunkey River. The species is abundant in more saline waters nearer the river mouths.

Fundulus heteroclitus macrolepidotus (Walbaum), Mummichog.-The mummichog was often captured in fresh water in the James and Rappahannock rivers and occasionally taken in the Pamunkey and Mattaponi. Adults were taken 45 miles upstream from brackish water. Numbers were observed spawning in a shallow cove 35 miles upriver from brackish water in the Rappahannock River, August 2, 1951.

Cyprinodon variegatus (Lacépède), Variegated minnow.-Many were captured in a tidal creek of the Rappahannock River where the salinity was less than five parts per thousand.

Menidia menidia (Limmens), Atlantic silverside.-Small numbers of adult $A$ tlantic silversides were taken as far as 30 miles upriver from brackish water in the James, Rappahannock, and Pamunkey rivers. In salt, water near the river months this species is common. 
NAUTIGAL MILES UPRIVER

SPEGIES

FUNDULUS HETEROCLITUS

MENIDIA BERYLLINA

ANCHOA MITCHILLI

STRONGYLURA MARINA

TRINECTES MACULATUS

BREVOORTIA TYRANNUS

MENIDIA MENIDIA

LEIOSTOMUS XANTHURUS -
MICROPOGON UNDULATUS
CYNOSCION NEBULOSUS

BAIRDIELLA CHRYSURA

PARALICHTHYS DENTATUS

CYNOSCION REGALIS

GOBIOSOMA BOSCI

ANCHOA HEPSETUS

CYPRINODON VARIEGATUS

FUNDULUS MAJALIS

PEPRILUS ALEPIDOTUS

\section{NUMBER OF SPECIES TAKEN}

$\begin{array}{lllllllllll}0 & 5 & 10 & 15 & 20 & 25 & 30 & 35 & 40 & 45 & 50\end{array}$

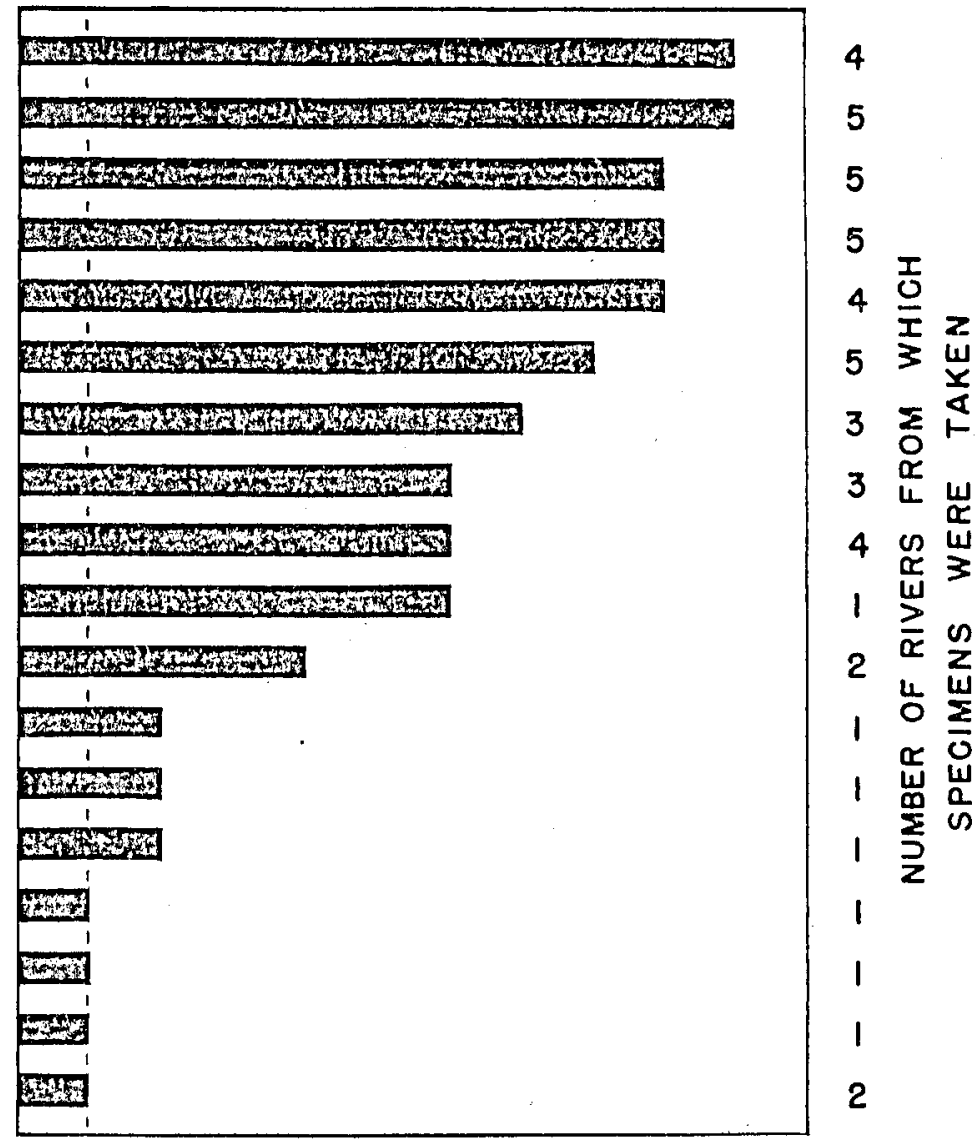

$\begin{array}{lllllllllll}18 & 14 & 11 & 11 & 10 & 10 & 7 & 6 & 5 & 2 & 0\end{array}$

FIG. 1. Greatest distance upriver from the average boundary of brackish and fresh waters that marine fishes have been taken in five Virginia rivers. The boundary is shown by a vertical, dashed line. The left hand margin represents a moan salinity of 5 parts per thousand.

Menidia beryllina (Cope), Glassy silverside.Ciencrally considered a marine species, glassy silversicles were collected as mutch as 45 miles upriver from brackish water in the Rappahannock River. Adults and young were common in the five rivers. Glassy silversicles appear to be more abunclant in fresh, tidal water than in salt water downstream.

Peprilus alepidotus (Linnacus), Harvestfish.Small numbers of harvestish were trawled in brackish waters of the Pamunkey and Mattaponi rivers.

Cynoscion regalis (IBloch and Schncider), Gray squeteague.-Small specimens were trawled five miles above brackish water in the Pamunkey River.

Cynoscion nebulosus (Cuvier and Valenciennes), Spotted squeteaguc.-Not listed by Cimter (1942) in fresh water, young spotted sque- teagte were obtained in surface trawl lauls from fresh water in the Rappahannock River. Of eleven specimens captured; two were taken 25 miles above brackish water.

Bairdiella chrysura (Lacépòde), Silver perch.A few young silver perch have been taken in the l'anmunkey and Rappahamock rivers at distances up to 15 miles above brackish waters.

Lciostomus ranthurus (lacépède), Spot.Young have been captured in the Pannmkey, Mattaponi, and Rappahannock rivers. Althongh spot were more abunchant near brackish waters, a few were found 25 miles farther upstream. Young spot collected in salt water (salinity 20 parts per thousand) were maintained in a laboratory tank of fresh tap water for a period of one month with no apparent ill effects.

Micropogon undulatus (I inmaens); Atlantic croaker.--Suall croakers were found in four riv- 
ers during the spring months. Three small individuals less than $30 \mathrm{~mm}$. in length were found 25 miles above brackish waters, but most were obtained closer to the sea. Recent work by Dexter Haven of the Virginia Fisheries Laboratory is establishing the importance of tidal estuaries as it croaker nursery ground.

Gobiosoma bosci (Lacépècle), Naked goby.Several gobies were collected in minnow seine samples up to five miles aloove brackish water in the Pamunkey River.

Paralichthys dentatus (Limnacus), Summer flounder.-A single specimen was seined in the Panunkey River five miles upriver from brackish water.

Trinectes maculatus (Bloch and Schneider), Hogchoker.-Hogchokers were common in the James, Pamunkey, Mattaponi, and Rappahannock rivers. Some were found 40 miles beyond brackish water. These fish were mostly small.

\section{Summary and Conclustons}

The transition from salt to fresh water in Virginia tidal estuaries is not alorupt. It is possible that very slight amounts of salt of marine origin may be present up to the head of ticle, but these amounts become increasingly difficult to detect by conventional methods at increasing (listances up)stream. Small amounts of salt water may become detached from the main body of salt water and moved upriver by eddies (Donakl W. Pritchard, personal communication). A series of salinity samples from the "fresh" tidal waters titrated with silver nitrate has indicated that salinities clid not decline steadily until they reached the normal salt content of fresh water, but seemed to show small crratic differences. Most of the salinities reported here were obtained by hydrometer readings, which cannot be considered accurate below one part per thousand. It is possible, therefore, that slight traces of salt may be responsible for the ability of some marine species to survive in waters considered to be "fresh."

Some marine species are able to adjust themselves to life in "fresh" water. The degree of adjustment varies among the different species and age groups. In the five Virginia rivers considered, the marine fishes may be divided into three general groups: (1) fishes commonly found in fresh water both as young and adults, including munmichog, glassy silverside, Atlantic needlefish, and Mitchill's anchovy; (2) fishes that occur in fresh water usually only as young, including hogchoker, menhaden, spot, Atlantic croaker, silver perch, and gray squeteagte; (3) fishes rarely taken either as young or adults, including spotted squeteague, winter flounder, Atlantic silversicle, and naked goby. To this last category might be adrled the fourspine stickleback, Apeltes quadracus (Mitchill), reported by Raney (1950) in fresh waters of the Rappahannock River.

\section{RETTRLNCES}

Gunter, Gordon. 1942. A list of the fishes of the mainland of North and Middle America recorded from both fresh water and sea water. Amer. Mid. Nat. 28: 305-326.

Massmann, William H., Ernest C. Ladd, and Henry N. McCutcheon. 1952. A surface trawl for sampling young fishes in ticlal rivers. Trans. 17 th $\mathrm{N}$. Amer. Wilclife Con1. : 386-392.

Raney, Edward C. 1950. Freshwater fishes. In: The James River lasin, Past, Present, and Future. Va. Acarl. Sci., Richmond, Virginia, pp. 151-194. 